Agnieszka BERNADKIEWICZ

IEiB UKSW Warszawa

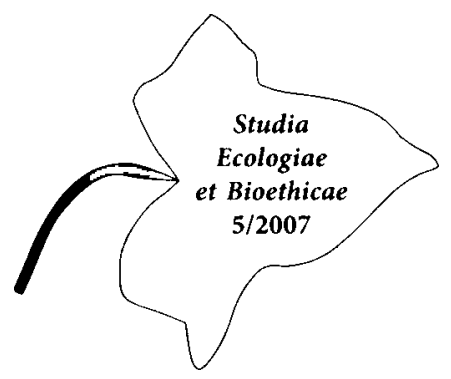

\title{
Sposoby ujmowania edukacji ekologicznej
}

W obecnych czasach relacja człowiek - przyroda opiera się przede wszystkim na czerpaniu przez ludzkość ze środowiska profitów, wykorzystywaniu jego zasobów do zapewnienia sobie lepszego bytowania. Sposoby, do jakich w tym celu ucieka się czlowiek przynoszą często niestety niekorzystne dla przyrody skutki, wiążące się niejednokrotnie $z$ jej nieodwracalnym przekształceniem. Środki oddziaływania jednostek na środowisko zależą niewątpliwie od stopnia ich świadomości ekologicznej, postępowania zgodnie z zasadami ekoetyki i poczucia odpowiedzialności za jego stan. Ochrona środowiska przed degradacją przez człowieka nie powinna sprowadzać się wyłącznie do wprowadzania zakazów prawnych oraz działalności organizacji i fundacji ekologicznych. W procesie tym jedną z ważniejszych ról odgrywa edukacja ekologiczna, której zadanie koncentruje się na wychowaniu człowieka poprzez kreowanie jego świadomości, osobowości, postawy proekologicznej. ${ }^{1}$

Edukacja ekologiczna - edukacja środowiskowa, edukacja sozologiczna, ekoedukacja - rozumiana jako wychowanie i wykształcanie człowieka nieobojętnego na środowisko przyrodnicze powstała w latach sześćdziesiątych XX wieku. W swojej treści zawiera ona aspekt biologiczny, abiotyczny, sozologiczny i społeczny. $\mathrm{W}$ tym rozumieniu w procesie nauczania należy uwzględnić zarówno wyżej wymienione aspekty, jak i informacje przekazywane przez nauki ekologiczne. ${ }^{2}$

Na rolę wychowawczą ekoedukacji zwraca uwagę również I. Fudali akcentując ponadto jej zadanie w kształtowaniu wrażliwości i emocjonalnej chęci działania na rzecz ochrony środowiska. ${ }^{3}$

A. KowALAK, Świadomość ekologiczna a realizacja idei rozwoju zrównoważonego, w: Współpraca międzynarodowa w edukacji ekologicznej. Materialy III Konferencji. Cyt. za W. SoвCzyк, Teoretyczna i eksperymentalna analiza edukacji ekologicznej mlodzieży, Kraków 2003, s. 14.

2 Por. J.M. DoŁĘGA, Sozologia w edukacji ekologicznej, w: Świadomość i edukacja ekologiczna, pod red. J. M. Dolęgi, J. Sandnera, Warszawa 1998, s. 143; tenże, Naukowe uwarunkowanie procesów ochrony środowiska, w: „Sozologia - edukacja ekologiczna i gospodarka odpadami”, 1 (2003), s. 12.

3 I. FudAli, Kultura ekologiczna mlodzieży, Kielce 2002, s. 201. 
Edukacja ekologiczna powinna być dopasowana do potrzeb i uwarunkowań ludzi, dostarczać im wiedzy pozwalającej pojąć czynniki (biologiczne, fizyczne, spoleczne, gospodarcze, kulturowe) wpływające na stan środowiska przyrodniczego. ${ }^{4}$

W. Sobczyk przyjmuje definicję, według której edukacja środowiskowa buduje właściwy obraz relacji pomiędzy człowiekiem, społeczeństwem i przyrodą, ukazuje kluczową rolę środowiska dla życia ludzkiego, a także wyczula na skutki, jakie może przynieść ingerencja człowieka w przyrodę. ${ }^{5}$

Zadania edukacji środowiskowej winny objąć także wyszczególnianie wartości i motywów, które mogą stać się przydatne lub wręcz niezbędne w chronieniu środowiska. Dlatego ekoedukację należy rozumieć jako ciągły proces rozciągnięty na całe życie, w trakcie którego każdy człowiek w teorii i praktyce przyswaja wiedzę rozwijającą umiejętności działania proekologicznego i (...) ksztatci wole indywidualnego i zbiorowego działania, aby w miarę swoich możliwości wziąć udział $w$ złożonym zadaniu naprawy stosunków między ludźmi a środowiskiem. ${ }^{6}$

I. Kozłowska edukację ekologiczną wiąże z psychologiczno - pedagogicznym rozwojem człowieka w celu budowania kultury ekologicznej, kształtowania wrażliwości na sprawy środowiska przyrodniczego i moralnego obowiązku jego chronienia. Autorka podkreśla konieczność kreowania osobowości ekologicznej poprzez rozwijanie indywidualnej oraz społecznej osobowości człowieka. ${ }^{7}$

Dąży się, aby edukację środowiskową powiązać z praktycznymi działaniami, $\mathrm{w}$ ramach których stawia się kłopotliwe pytania, pozwalające poznać powody cierpienia przyrody i możliwości ich rozwiązywania. Chodzi o przyjęcie radykalnej edukacji ekologicznej, by szybko i skutecznie podjąć czynności ratujące przyrodę. ${ }^{8}$

Edukacja środowiska posiada szeroki zakres treści i metod nauczania. $Z$ jednej strony przekazuje niezbędne informacje o środowisku, $z$ drugiej dąży do rozwijania u ludzi uniwersalnych zdolności i zachęca ich do angażowania się w praktyczne akcje na rzecz środowiska czy to na szczeblu szkoły, dzielnicy, gminy, czy też miasta. ${ }^{9}$ Proces ten powinien sprowadzać się do zespolenia wszystkich elementów nauczania w celu kształtowania całościowej wizji świata. Nie należy zatem odseparowywać zagadnień ekologicznych, ale raczej wiązać je z ogólnospołecznymi problemami, by nie spotykały się z ludzką obojętnością.

4 Por. E. Trzaskowska, O potrzebie i formach edukacji ekologicznej, w: Humanizm ekologiczny, pod red. L. Pawłowskiego, s. Zięby, Lublin 1992, s. 97.

5 Por. W. SовсZук, Teoretyczna i eksperymentalna analiza..., s. $14-15$.

6 E. Trzaskowska, O potrzebie i formach edukacji ekologicznej, w: Humanizm ekologiczny, pod red. L. Pawłowskiego, S. Zięby, Lublin 1992, s. 97.

7 Por. I. KozıowsKA, Edukacja ekologiczna studentów, w: Edukacja i świadomość ekologiczna, pod red. A. Pfeiffera, Poznań 1997, s. 45.

8 Por. J. Korbel, M. Lelek, W obronie Ziemi - radykalna edukacja ekologiczna, Bielsko-Biała 1995, s. 68.

9 Por. L. TuszYŃSKA, Edukacja ekologiczna dla nauczycieli i studentów, Warszawa 2005, s. 5. 
L. Tuszyńska wskazuje na następujące obszary działalności ekoedukacji:

- obszar przyrodniczo-techniczny - dotyczy sprecyzowania wymogów i zakazów postępowania wobec środowiska, sposobów przewidywania szkód i naprawiania już istniejących;

- obszar działalności politycznych, społecznych, prawnych i ekonomicznych;

- obszar działań wychowawczych odnoszący się do świadomości indywidualnej i społecznej - podejmowanie wszelkich inicjatyw w kierunku działań prośrodowiskowych , których organizatorami byliby ludzie z wysokim poziomem świadomości ekologicznej, kierujący się ekowartościami. ${ }^{10}$

Wyróżnia się trzy podstawowe nurty koncepcji edukacji ekologicznej:

- nurt konserwatywny

- nurt radykalny

- nurt umiarkowany

Nurt konserwatywny bazuje na naukach o Ziemi, opowiada się za dostarczeniem autentycznej wiedzy o przyrodzie z pominięciem aspektów społeczno-gospodarczych. Nurt radykalny, wywodzący się z ekologii głębokiej, odrzuca antropocentryzm i dąży do egalitaryzmu. Reprezentanci tego stanowiska koncentrują się na roli bezpośredniej styczności człowieka z przyrodą nie zgłębiając przy tym rzetelnych o niej informacji. Najbardziej preferowany w ekoedukacji jest nurt umiarkowany oparty na filozofii ekorozwoju. Jego zwolennicy scalają wiedzę o środowisku $\mathrm{z}$ wychowaniem i działaniem. Rola edukacji ekologicznej, w myśl tego nurtu, sprowadza się do rozbudzenia w człowieku sumienia ekologicznego, wrażliwości na piękno przyrody i napędza go do podejmowania praktycznych przedsięwzięć na rzecz środowiska. ${ }^{11}$

Podobnie, jak każda edukacja także edukacja ekologiczna zawiera pewne treści, do których można zaliczyć:

- wiedzę o ekologii jako nauce o związkach i zależnościach występujących pomiędzy organizmami a ich środowiskiem;

- wiedzę na temat powiązań ekologii z innymi naukami;

- wiedzę dotyczącą podstawowych terminów i pojęć ekologicznych,

- wiedzę z zakresu historii ochrony środowiska przyrodniczego w Polsce i na świecie;

- wiedzę o globalnych wskaźnikach utrzymania równowagi ekologicznej;

- wiedzę o kierunkach ochrony środowiska;

- wiedzę o skażeniach powietrza i sposobach jego ochrony przed zanieczyszczeniami;

- wiedzę dotyczącą zasobów i ochrony zbiorników wodnych;

- wiedzę o czynnikach degradacji gleb i możliwościach jej ochrony;

10 Tamże, s. 7.

11 Por. W. SoвсzYк, Teoretyczna i eksperymentalna analiza..., s. 15; por. J. KorbeL, M. LELeK, W obronie Ziemi..., s. $66-67$. 
- wiedzę o roślinach, ich pozytywnych zasługach w oczyszczaniu powietrza, tłumieniu hałasu oraz wpływie na mikroklimat i życie człowieka;

- wiedzę na temat zagrożeń dla człowieka wynikających z zanieczyszczeń i katastrof ekologicznych w środowisku;

- wiedzę z zakresu prawa ochrony środowiska;

- wiedzę dotyczącą zasad i norm etycznych w ochronie środowiska przýrodniczego;

- wiedzę o znaczeniu ekologii i ochrony środowiska dla dziedzictwa kulturowego człowieka;

- wiedzę o problemach ekologicznych występujących w środowiskach lokalnych. ${ }^{2}$

Niewątpliwie edukacja ekologiczna powinna być procesem rozciągniętym w czasie, realizowanym od pierwszego etapu kształcenia dzieci w ramach edukacji szkolnej (edukacja ekologiczna formalna) po wyższe grupy wiekowe działające za pośrednictwem wszelkich instytucji i organizacji społecznych (edukacja ekologiczna nieformalna). ${ }^{13}$

\title{
The ways of expressing ecological education
}

\author{
SUMMARY
}

Recently, relation between human being and nature is mainly that environmental resources are gained by people to assurance themselves worthy living conditions. People's actions are often not very well motivated, leading to serious consequences such as degradation of environmental components. The way of making use of biosphere components are undoubtedly depend on degree of ecological awareness and on people's responsibility for environment. A creation of pro-ecological attitudes is one of main goals of ecological education.

This article shows the ways of understanding ecological education, the areas of its interest, its essence, and the most important trends and values in the contemporary world.

12 Por. J. FratczaK, Świadomość ekologiczna dzieci, młodzieży i dorostych..., s. 160.

13 Przez edukację do zrównoważonego rozwoju. Narodowa Strategia Edukacji Ekologicznej, Warszawa 2001. 